\title{
POTENTIAL ENVIRONMENTAL IMPACTS OF PHOTOVOLTAIC SOLAR ENERGY ON INDUSTRY
}

\author{
POTENCIAIS IMPACTOS AMBIENTAIS DA ENERGIA SOLAR FOTOVOLTAICA NA \\ INDUSTRIA
}

Recebido em: 22 dez. 2020

Aprovado em: 20 mar. 2021

Versão do autor aceita publicada online: 20 mar. 2021

Publicado online: 30 jun. 2021

Como citar esse artigo - American Psychological Association (APA):

Franco, A. C., Ravagnani, M. A. S. S., \& Franco, L. S. (2023, jan./mar). Potential environmental impacts of photovoltaic solar energy on industry Exacta, 21(1), 249-269. https://doi.org/10.5585/exactaep.2021.18998

Submeta seu artigo para este periódico

Processo de Avaliação: Double Blind Review

Editor: ${ }^{D}$ Dr. Luiz Fernando Rodrigues Pinto

Dados Crossmark 



\title{
POTENTIAL ENVIRONMENTAL IMPACTS OF PHOTOVOLTAIC SOLAR ENERGY ON INDUSTRY
}

\author{
POTENCIAIS IMPACTOS AMBIENTAIS DA ENERGIA SOLAR FOTOVOLTAICA NA INDÚSTRIA
}

\author{
(iD) Antonio Carlos Franco ${ }^{1}$ \\ Mauro Antonio da Silva Sá Ravagnani² \\ (iD) Luciane Silva Franco ${ }^{3}$
}

\begin{abstract}
Solar energy is considered one of the most importants renewable energy resources to decrease the dependence on fossil fuels. Therefore, this study aims to conduct a systematic review of the literature on high impact research on the environmental impacts avoided with the use of solar photovoltaic energy in the industrial sector to investigate trends in this body of literature. To this end, filters were applied to the gross portfolio between 209 articles and 22 were selected to identify the most relevant and high impact studies in the area. The results show the main trends in the referred body of literature, possible connections of photovoltaic solar energy and environmental impacts in the industry, as well as the main researchers who carry out studies. This study provides an overview of the impacts avoided with the use of solar photovoltaic energy in the possibilities of future research.
\end{abstract}

Keywords: renewable energy. bioenergy. solar energy. environmental impacts. industrial sector.

Resumo: A energia solar é considerada um dos recursos de energia renovável mais importantes para diminuir a dependência de combustíveis fósseis. Portanto, este estudo tem como objetivo realizar uma revisão sistemática da literatura sobre pesquisas de alto impacto sobre os impactos ambientais evitados com o uso da energia solar fotovoltaica no setor industrial para investigar tendências neste corpo da literatura. Para tanto, foram aplicados filtros ao portfólio bruto entre 209 artigos e selecionados 22 para identificar os estudos mais relevantes e de alto impacto na área. Os resultados mostram as principais tendências do referido corpo da literatura, as possíveis conexões da energia solar fotovoltaica e os impactos ambientais na indústria, bem como os principais investigadores que realizam os estudos. Este estudo fornece uma visão geral dos impactos evitados com o uso da energia solar fotovoltaica nas possibilidades de pesquisas futuras.

Palavras-chave: energia renovável. bioenergia. energia solar. impacto ambiental. setor industrial.

\footnotetext{
${ }^{1}$ Universidade Estadual de Maringá / Mestrado em Bionergia pela Universidade Estadual de Maringá e Engenheiro Mecânico pela Universidade Positivo

2 Universidade Estadual de Maringá - UEM / Na UEM é Professor Titular, lotado no Departamento de Engenharia Química, atuando como orientador de alunos de Mestrado e Doutorado no Programa de Pós-Graduação em Engenharia Química, de alunos de Mestrado no Programa de Pós-Graduação em Bioenergia e de alunos de Mestrado no Programa de Pós-Graduação em Engenharia de Produção da UEM. Doutor em Engenharia Química pela Universidade Estadual de Campinas - Unicamp. Pós-doutorado na Universidade de Alicante - UA Espanha. Bolsista do Conselho Nacional de Desenvolvimento Científico e Tecnológico - Processos 311807 / 2018-6 e 428650 / 2018-0 - CNPq (Brasil)

${ }^{3}$ Universidade Tecnológica Federal do Paraná (UTFPR) / Graduação em Administração pela Universidade Estadual do Paraná. Mestrado em Engenharia de Produção pela Universidade Tecnológica Federal do Paraná (UTFPR)
} 
Introduction

Solar energy is a renewable and sustainable energy alternative for the supply of electricity on a small and large scale (Paines, Vignochi, \& Possamai, 2018). Clean energy sources have received growing support owing to concerns around the world in climate change mitigation (Ha, Byrne, Lee, Lee, \& Kim, 2020). The 4th IPCC Assessment Report, published in 2007, reports that climate change has raised concerns among policy makers, the general public and researchers (Noh et al., 2020). To contribute the global concern about climate change and greenhouse gas emission, solar energy is supposed to be one of the optimal options (Adenle, 2020). Solar energy sources are abundant and more competitive than conventional fossil fuels in the generation of electricity (Venkata Sai \& Reddy, 2020). The rapid deployment of solar energy in the world is the result of ambitious political support, such as tariffs for energy generation and distribution and the abundant solar sources on the planet (Li, Liu, Jiang, \& Chen, 2020; Stoicanescu et al., 2019).

However, even with this progress, global solar energy still has great challenges to be overcome during the energy generation process (Shlikhter, 2018). Several researchers claim that solar energy is a clean source of energy for reducing current dependence on fossil fuels (Hamid, Bagher, Reza, \& Mahboubeh, 2016; Rey-Martínez, Velasco-Gómez, Martín-Gil, Navas Gracia, \& Hernández Navarro, 2008). Solar energy shows advantages to the environment for carrying out activities in a sustainable way for people in the industrial system (Branker \& Pearce, 2010). Countries have invested in renewable energy such as photovoltaic solar energy to generate energy in production systems. The use of photovoltaic solar energy systems in the industry reduces the carbon footprint and contributes to reducing the quantities of greenhouse gas emissions (Duarte \& Malheiros, 2015).

The mainstream of literature has been intensively focused on the following fields of solar energy, including the solar technology standards (Venkata Sai \& Reddy, 2020); economic returns of investment (Korkmav, Unsal, Gorgun \& Avci, 2020; Noh et al., 2020) and cost analysis (SamaniegoRascón, Gameiro da Silva, Ferreira \& Cabanillas-Lopez, 2019).

Government R\&D funds have been found by researchers to contribute to the popularization of solar photovoltaic energy by reducing costs and environmental impacts (HA et al., 2020; Stoicanescu et al., 2019; Corona, Bozhilova-Kisheva, Olsen \& San Miguel, 2017).

Several countries have researched the development of technologies and policies related to the reduction of environmental impacts with the use of photovoltaic solar energy. Research findings show that R\&D funding impacts the photovoltaic market in countries around the world (Shlikhter, 2018; Grippo, Hayse \& O'Connor, 2014; Branker \& Pearce, 2010). There was a significant increase in investments in R\&D in PV, which encouraged the expansion of the PV market, reducing environmental impacts and reducing material costs (Ha et al., 2020; Rey-Martínez et al., 2008). 
Several publications focus on government R\&D to emphasize the role of the government system in the PV strategy and to reduce impacts on the environment (Noh et al., 2020; Branker \& Pearce, 2010).

The use of photovoltaic technologies improves the efficiency of investment in R\&D. The research linked projects with the main countries in PV R\&D and research led by various government departments, suggesting that their link may facilitate market development (Ha et al., 2020; Korkmav et al., 2020; Li et al., 2020; Shlikhter, 2018; Duarte \& Malheiros, 2015).

In the literature, there have been a large number of studies analyzing clean sources for power generation development. The literature has been intensively focused on the following fields of clean energy sources: benefit analysis (Stoicanescu et al., 2019; Branker \& Pearce, 2010); renewable structure (Venkata Sai \& Reddy, 2020); economic return on investment (Grippo et al., 2014; Lamont \& El Chaar, 2011) and cost analysis (Noh et al., 2020; Tan et al., 2012).

Therefore, this study aims to carry out a systematic review of the literature on high-impact research on the environmental impacts avoided with the use of solar photovoltaic energy in the industrial sector to investigate trends in this body of literature. The study is structured as follows. This section presented the initial considerations, the purpose of the study and its originality.

Therefore, this study aims to carry out a systematic review of the literature on high-impact research on the environmental impacts avoided with the use of solar photovoltaic energy in the industrial sector to investigate trends in this body of literature. The study is structured as follows: this section presented the initial considerations, the purpose of the study and its originality.

The next section of this article presents the theoretical background and the methods adopted for the development of this study. Following, the main trends, discussions on the theme and on which they are based are presented. At the end, the final considerations of this study are elaborated.

\section{Theoretical Background}

\section{Renewable Energy}

Renewable energies have been one increasing research topic in reducing environmental impacts (Tan et al., 2012). Achieving sustainable development is an important goal for global public opinion (Adenle, 2020). Energy is a critical issue for the survival of human civilization (Chen, Wan, \& Long, 2013). Current energy generation is one of the most controversial problems, as fossil fuels are polluting (Hamid et al., 2016; El-Shobokshy \& Al-Saedi, 1993). Difficulty in global access to electricity is a common problem encountered in developing country economies (Corona et al., 2017; Rey-Martínez et al., 2008).

Renewable energy generation is growing globally, as part of long-term strategies aimed at reducing greenhouse gas emissions, and to achieve a sustainable energy supply. It is known that the 
electric energy generated, mainly, based on fossil fuels, can generate damage to the environment through the emission of toxic particles and gases (Duarte \& Malheiros, 2015; Chen et al., 2013).

Renewable energy is a form of energy that can be replenished from energy sources in nature. These clean energy sources are freely generated, but are intermittent and none exhaustible (Contreras, Carpio, Molero, \& Veziroglu, 1999). Non-renewable energy is the products collected by nature for the generation of energy for a very long period and, if exhausted, there is no replenishment. Examples of non-renewable energies are fossil fuels such as natural gas, petroleum, coal, etc. (Adenle, 2020). Clean sources of energy are used to contribute to problems of the energy crisis in several sectors, as these are environment-friendly and almost limitless (Noh et al., 2020).

The alarming scenario of pollution and environmental degradation is the main reason that drives the most responsible generation of renewable energy (Grippo et al., 2014). With the innovation rising at its peak, the need for electricity has increased exponentially. Researchers are persistently studying ways to supply this demand and supply (Branker \& Pearce, 2010). One of the feasible possibilities is the use of clean energy from renewable resources (Hamid et al., 2016). The population increase in the world represents a distinct increase in energy consumption. It is estimated that, by the year 2050, global energy consumption will grow 45\% (Korkmav et al., 2020). With the growth in energy demand in the industrial sector, researchers are forced to look for new ways to meet the development of energy demand (Dubey, Jadhav \& Zakirova, 2013; Lamont \& El Chaar, 2011). These energy demands are met in two ways: the use of non-renewable sources and renewable sources (Li et al., 2020; Stoicanescu et al., 2019).

Non-renewable energy cannot be replenished at sufficient rate and concern over sustainability of these resources (Samaniego-Rascón et al., 2019). Non-renewable sources face some disadvantages when compared to renewables (Adenle, 2020; Li et al., 2020). Non-renewable sources will be extinguished, as they are used at a very high rate (Corona et al., 2017). There is a high environmental risk, as non-renewable energy resources show great damage to the environment (Lamont \& El Chaar, 2011; Rey-Martínez et al., 2008). The use of renewable energy and rational use of energy will become increasingly relevant in the medium and long term (Shlikhter, 2018). Renewable energies have grown due to activity interests in the world in reducing climate change (Tan et al., 2012). Currently, due to the need to reduce global warming and environmental pollution, industrial activities are dependent of nonrenewable energy supply and responsible for great impact (Noh et al., 2020).

\section{Solar energy}

In response to the global concern about the negative effects on the environment, such as climate change and the emission of polluting gases, solar energy is supposed to be one of the optimal 
options (Noh et al., 2020). The use of solar energy shows several positive factors with government systems, including subsidies and financing. China is one of the countries with the largest set of fiscal and financial incentives (Elgamal \& Demajorovic, 2019).

Generating electricity through fossil fuels generates harmful gases of methane and carbon that reduce air quality, which can have consequences for human and animal healt (Corona et al., 2017).

The use of solar energy means less and less environmental damage caused by burning fossil fuels. The production of energy by solar panels is not harmful to the environment, and therefore, the more distribution systems with solar energy, the air receives less fuel emissions (Shlikhter, 2018; Corona et al., 2017; Tan et al., 2012).

Photovoltaic solar energy is widely abundant and is becoming more competitive compared to conventional fossil fuels in electricity production, with lower costs in industrial facilities (Adenle, 2020). One study developed in Spain says the life cycle of greenhouse gas emissions from photovoltaic solar energy is less than fossil energy (Samaniego-Rascón et al., 2019).

Solar energy is a sustainable technology, this type of renewable energy is classified into active methods, as they are used to orient the active solar devices for maximum expose to radiant energy (Hamid et al., 2016). The benefits of solar energy over other renewable energies are: the equipment has easy installation, possibility of generating energy in several areas, the technology has a long service life in relation to the energy generated by wind and hydroelectric power and the simple replacement of solar panels (Li et al., 2020; Contreras et al, 1999).

Solar energy has abundant availability and easy accessibility (Ha et al., 2020). The role of photovoltaic solar energy is theorized to be able to lower the burden on scarce renewable resources and to supply clean energy in conditions where no alternatives are available (Branker \& Pearce, 2010). The use and conversion of photovoltaic solar energy is a possibility to meet the demands of the industrial energy sector and also to reduce the environmental impacts that compromise social well-being (Shlikhter, 2018). Many researchers believe that the eventual solution for sustainable energy is the use of photovoltaic solar energy as the main source of energy in the industrial sector (Adenle, 2020; Korkmav et al., 2020; Li et al., 2020; Noh et al., 2020; Venkata Sai \& Reddy, 2020; Rey-Martínez et al., 2008).

Among the options for renewable sources, photovoltaic solar energy offers a sustainable way to take advantage of an unlimited resource and low environmental impact in contrast to other available energy alternatives (Samaniego-Rascón et al., 2019). Therefore, it is logical that the industrial sector, considered as one of the biggest consumers of fossil fuels, studies new energy generation systems based on clean energy sources that do not pollute and are inexhaustible like solar energy (Corona et al., 2017). Industrial production facilities in the world of the photovoltaic market have achieved significant development in recent decades (Samaniego-Rascón et al., 2019). 
With recent improvements in technologies for clean energy generation, solar photovoltaic energy is rapidly approaching economic competitiveness in relation to the energy generated from fossil fuels (Lamont \& El Chaar, 2011). Much of the electricity generated by photovoltaic solar energy in the industrial sector is derived from sources distributed on the roof of administrative buildings and offices (Hamid et al., 2016). Currently, several solar photovoltaic installations in the industrial sector are in operation on private land and additional facilities are under construction (Adenle, 2020). The researchers found that government system funds contribute to the popularization of photovoltaic solar energy, reducing costs, improving efficiency and decreasing environmental impacts (Chen et al., 2013; Tan et al., 2012).

\section{Methodology}

A systematic review based on high impact articles was used to build the present study's portfolio, presented in Figure 1. This study used the ScienceDirect, Scopus and Web of Science databases to search articles and review articles, without time limit. The authors chose the Scopus and Web of Science databases as they are among the largest bibliographic references in science in the multidisciplinary field. In addition, applied and basic source research is available in a wide coverage of journals with a high impact factor (Norris \& Oppenheim, 2007). Due to the search for research involving the environment and impact on human health, ScienceDirect was used, as it presents scientific and technical research in the health field (Elsevier, 2020).

The set of keywords used in the search was defined using truncation symbols and Boolean operators, as follows: ("solar energy" AND "environment" AND "impact" AND "industry"). After searching the databases, 209 articles were found (as observed in Figure 1). 
Figure 1

Summary of literature review steps

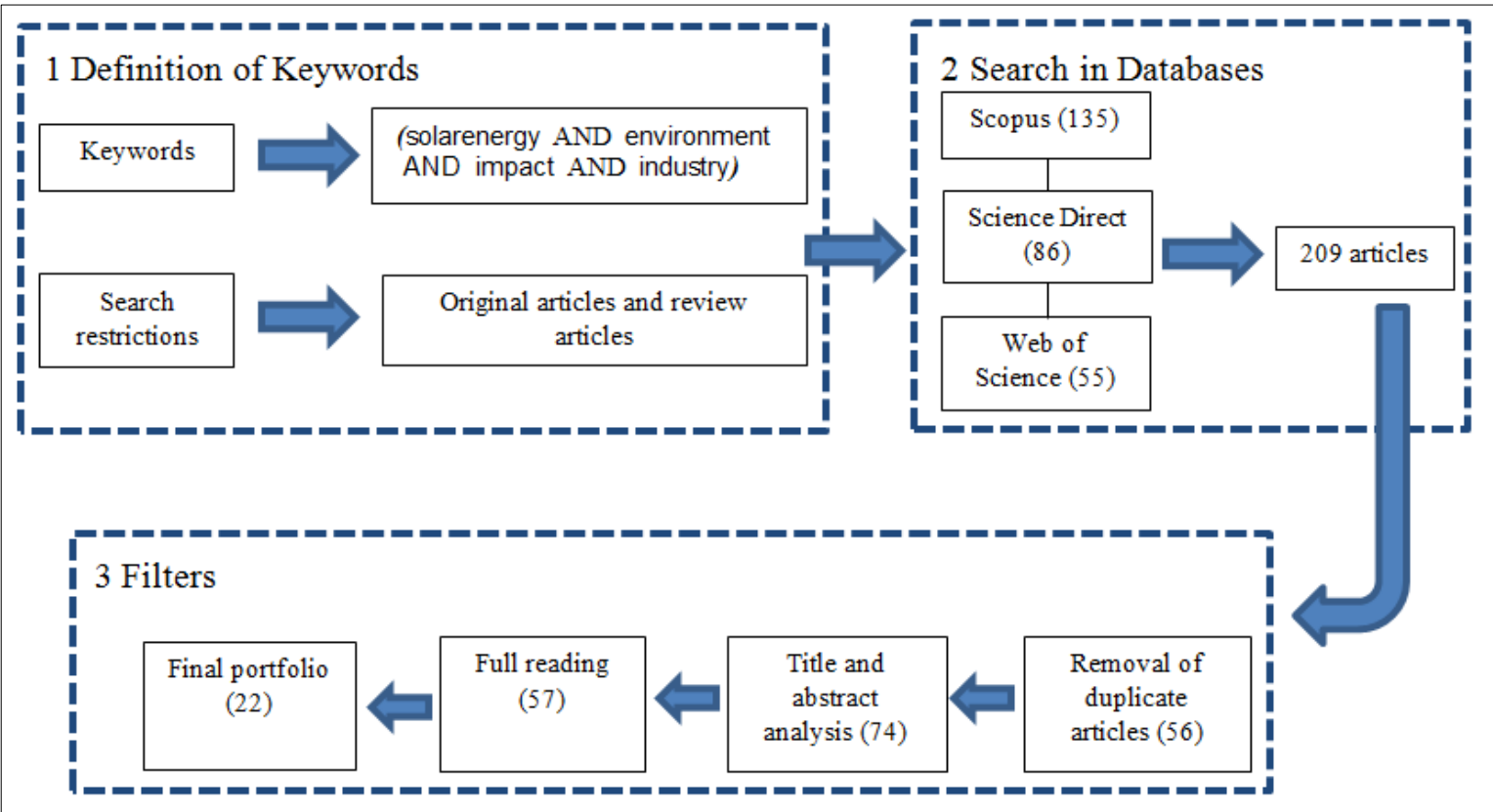

Source: Own Authorship (2020).

Thereafter, a series of filters and ranking techniques were applied in order to find the relevant and most impacting studies to be fully analyzed, since the assessment of all the documents encountered would be impractical time wise. Therefore 209 articles remained. In summary, duplicate articles were excluded from the final portfolio. From the 209 articles, 153 remained for analysis. After the title and abstract filter, since there were studies that did not fit in this research, there were 22 left. Thereafter, the number of citations (using Google Scholar) and the IF (using the Journal Citation Reports (JCR) were obtained in December 2020.

The application of such method helped identify high impact research conducted on this study's theme without time limit. At last, after full reading of the remaining articles, the ones found not tied to this review's topics were excluded from the portfolio.

The documents were managed using Mendeley reference manager. The following analysis techniques were used: citation analysis, co-occurrence of terms and words and co-authorship. The citation analysis involves several aspects of a research field, such as the influence of articles in relation to the year of publication, countries and journals. It is a measure of influence through which citation is considered a tool (Van Raan, 2003).

The study also performed the co-occurrence technique by terms and words, thus providing mapped word flows, which formed clusters of concepts and helped to identify the main research trends. Finally, the co-authorship technique was used to perform an analysis of the relationships between authors and co-authors, through the formation of clusters (Castro \& Frazzon, 2017). Term-co- 
occurrence and Co-authorship visual maps were constructed assisted by the VOSviewer software tool. VOSviewer is a software tool for building and visualizing bibliometric networks for easy interpretation (Van Eck \& Waltman, 2009).

To perform the full analysis of the final portfolio, some characteristics were taken into consideration. Besides the year of publication, country, journal, authors, impact factor of the journal and the number of citations, the remaining observed and assessed characteristics were: main environmental impacts avoided with the use of photovoltaic solar energy.

\section{Results and discussion of the characteristics found in the studies}

Results are based on the final set of 22 articles considered of high impact having gone through the whole set of ruling out criteria, described in the Methods section. Final portfolio of articles used in the study between 1993 and 2020, as shown in Table 1.

\section{Table 1}

Characteristics of the assessed studies (number of citation and impact factor) Article

High performance photovoltaic applications using solution-processed small molecules (Chen et al., 2013).

A review of solar energy driven desalination technologies (Sharon \& Reddy, 2015).

Socio-Economic and Environmental Impacts of Silicon Based Photovoltaic (PV)

Technologies (Dubey et al., 2013).

Solar-hydrogen: An energy system for sustainable development in Spain

(Contreras et al., 1999).

Financial return for government support of large-scale thin-film solar photovoltaic manufacturing in Canada (Branker \& Pearce, 2010).

Social Life Cycle Assessment of a Concentrated Solar Power Plant in Spain: A Methodological Proposal (Corona et al., 2017).

Life cycle analysis of a thermal solar installation at a rural house in Valladolid Spain (Rey-Martínez et al., 2008).

Enhancement of a stand-alone photovoltaic system's performance: Reduction of soft and hard shading (Lamont \& El Chaar, 2011).

Solar Energy Development and Aquatic Ecosystems in the Southwestern United States: Potential Impacts, Mitigation, and Research Needs (Grippo et al., 2014). Photovoltaic power generation in China: Development potential, benefits of energy conservation and emission reduction (Tan et al., 2012).

The impact of the gulf war on the Arabian environment-I. Particulate pollution and reduction of solar irradiance (El-Shobokshy \& AI-Saedi, 1993).

Making the case for solar energy (Price, 2008).

Review on hybrid geothermal and solar power systems (Li et al., 2020).

Assessment of solar energy technologies in Africa-opportunities and challenges in meeting the 2030 agenda and sustainable development goals (Adenle, 2020).

Review of sustainable energy sources in Kerman (Hamid et al., 2016).

\section{Year}

2013

2015

2013

1999

2010

2017

2008

2011

2014

2012

1993 18

2008

2020

2020

2016 
4-E (Energy-Exergy-Environment-Economic) analyses of integrated solar powered jaggery production plant with different pan configurations (Venkata Sai \& Reddy, 2020).

Solar energy industry workers under climate change: A risk assessment of the level of heat stress experienced by a worker based on measured data (Samaniego-Rascón et al., 2019).

High-humidity processed perovskite solar cells (Noh et al., 2020).

2020

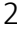

2019

1

2020

0

Energy Efficiency in Lumber Drying - Sample of Drying Red Pine (Pinus brutia)

Using Solar Energy (Korkmav et al., 2020).

Heat treatment of steel 1.1730 with concentrated solar energy (Stoicanescu et al., 2019).

Assessing the impact of R\&D policy on PV market development: The case of South Korea (Ha et al., 2020).

Paris climate conference and priorities of Donald Trump's energy policy

(Shlikhter, 2018).

Source: Own Authorship (2020).

The study by Chen et al. (2013), appears most prominently in the number of referenced citations. The research portrays that the aspect of life time is related to the degradation that photovoltaic cells, reducing the useful life and generating loss of efficiency of the cells in converting sunlight into electrical energy. The long-term reliability of photovoltaic modules is necessary so that photovoltaic technology can be a commercially viable option for energy generation and distribution. The main factors responsible for the degradation of photovoltaic cells are: humidity, solar radiation and temperature.

Sharon and Reddy (2015) present the second study with the highest number of referenced citations. The paper highlights that the competitive market for solar energy technology is determined by the environmental factor and efficiency factors. There is a growing concern to improve and efficiency and cost reduction in the various types of solar cells available in the industrial sector. It is noticed that Chen et al. (2013) and Sharon and Reddy (2015), present a relationship between their studies, since photovoltaic energy generation technologies need to have acceptable resources in return times.

Thus, the development of the application of photovoltaic solar energy in the industrial sector directly impacts the environment, providing benefits such as the reduction of gases responsible for the greenhouse effect $(\mathrm{GHG})$, avoids acid rain and global warming, diversification of the energy matrix, minimizes problems of energy rationing due to periods of drought, the industry shows a sustainable image to its customers.

The main research areas on the topic of avoided environmental impacts with the use of photovoltaic solar energy in the industrial sector were identified, and the articles were classified according to their main research area, as shown in Figure 2. 
Figure 2

Photovoltaic solar energy research field (1993-2020) with the number of publications per theme

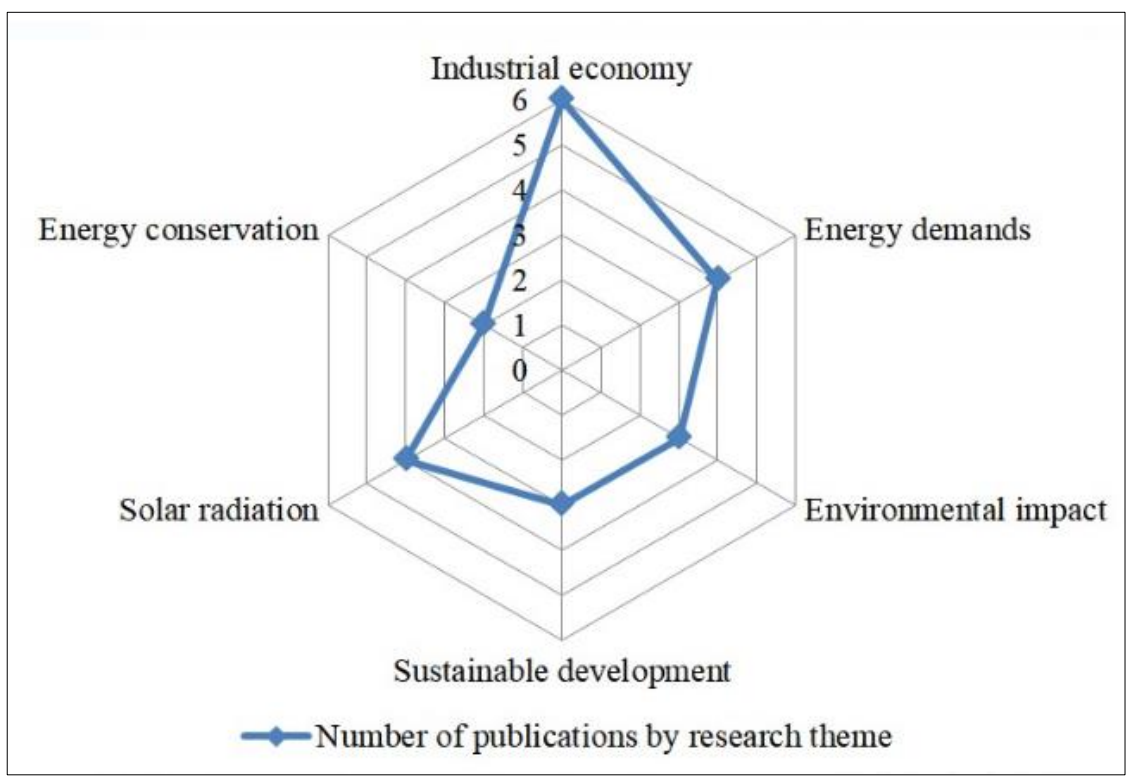

Source: Own Authorship (2020).

The two main themes, industrial economy and energy demands, indicate that the studies are focused on supply and demand for photovoltaic energy in the industrial sector. The reduction in operating costs and an integrated energy management system enables an economical industrial demand in the production process and a responsible attitude. In addition, the literature presents a beginning of concern with sustainability, mainly in relation to the environmental impact in the industrial sector, a beginning of development in the field of research can be perceived, but it is still necessary to develop this theme (Venkata Sai \& Reddy, 2020; Dubey et al., 2013). In the literature, the main environmental impacts avoided with the use of solar photovoltaic energy in the industrial sector were identified: burning and deforestation (El-Shobokshy \& Al-Saedi, 1993); visual and noise pollution (Samaniego-Rascón et al., 2019); emission of gases responsible for the greenhouse effect (Adenle, 2020); flooding of ecosystems (Sharon \& Reddy, 2015); risk of serious accidents based on nuclear energy (Corona et al., 2017); lack of waste recycling (Grippo et al., 2014).

Therefore, the social scope, the inclusion of the development of sustainability to promote the use of clean energy (Hamid et al., 2016); stands out in the literature, since none of the evaluated studies has as main theme the social scope, that is, quality of life (Tan et al., 2012); social inequalities (Noh et al., 2020); clean and accessible energy for local communities (Venkata Sai \& Reddy, 2020); reducing problems with dependence on fossil energies (Stoicanescu et al., 2019; Rey-Martínez et al, 2008); that is, a barrier in the sustainability dimension as the little incentive for the development of solar photovoltaic energy in the industrial sector, mainly in developing countries with this visible reality ( $\mathrm{Ha}$ 
et al., 2020). The use of clean energy stimulates the growth of the economy, without environmental impacts (Korkmav et al., 2020; Li et al., 2020; Noh et al., 2020; Samaniego-Rascón et al., 2019; Hamid et al., 2016). Figure 3 shows the articles according to the year of publication, showing a trend of evolution of the concept.

\section{Figure 3}

\section{Number of publications per year}

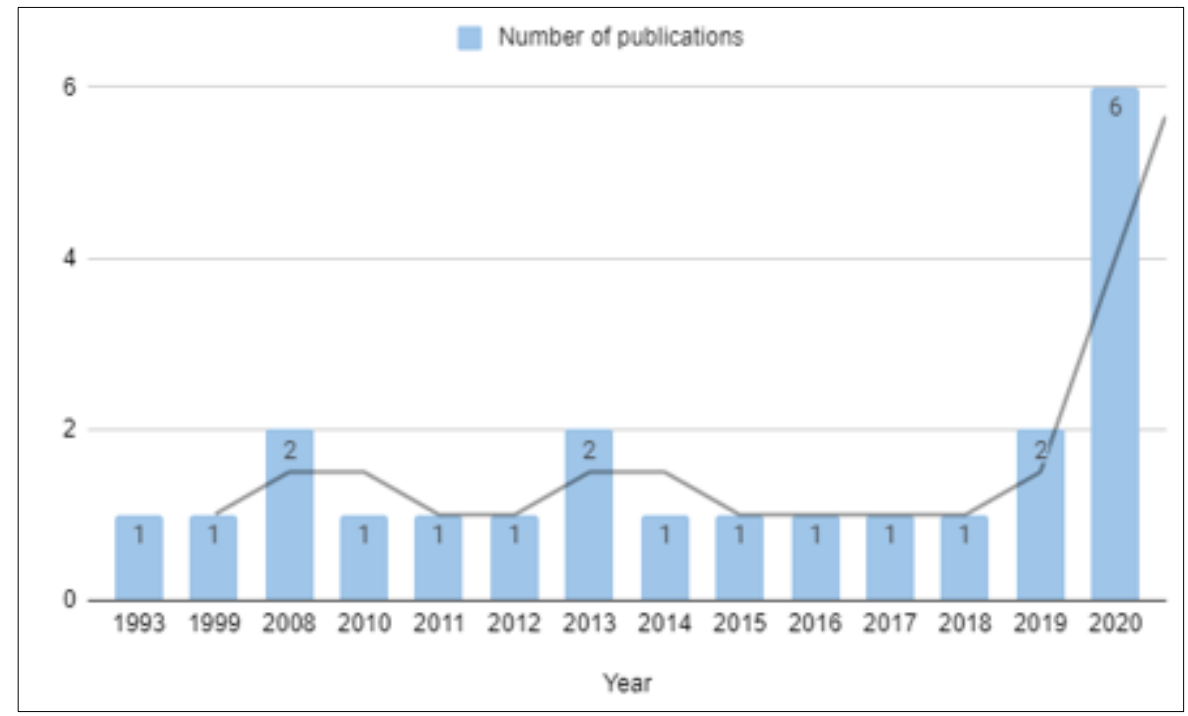

Source: Own Authorship (2020).

In the geographic analysis, it can be seen the number of publications by country, since the first high impact article found through the classification method of this study. There seems to have been an increase in the number of publications on the topic over time, however, it is still too early to reach conclusions on trends, since there is still no extensive history.

However, one of the main concerns seems to be the avoided environmental impact with the use of photovoltaic solar energy in the industrial sector, since most studies address possible environmental damage. Europe and Asia occupy a leading position in the production of power produced from solar energy. Such approach yet seems to be globally addressed, since studies have been carried out in China, Spain, United States, India, Canada, Singapore, Saudi Arabia, Iran, Portugal, Malaysia, Turkey, Romania, Korea Russia and the United Arab Emirates. Only Africa does not seem to have had much concern with the issue so far. However, there can be seen a massive contribution from China, Spain, United States to the theme's development, once 9 out of the 22 articles fully assessed. Figure 4 shows the countries with the largest academic output on the environmental impacts avoided with the use of solar photovoltaic energy in the industrial sector. 
Figure 4

Number of publications per country

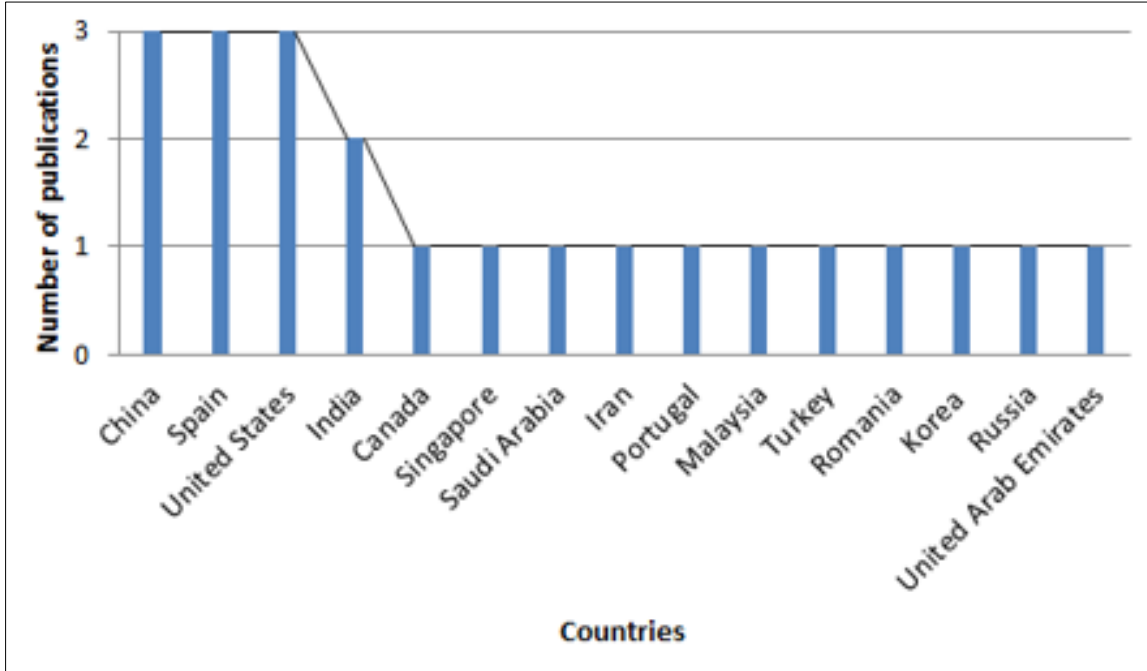

Source: Own Authorship (2020).

Research shows that China has a potential for developing photovoltaic power generation. Some factors were representative for the development of the photovoltaic market, which involve the growth of the photovoltaic industry and the existence of government regulations and supporting policies. Although it has reached a leading level of research and development in solar cells worldwide. Progress is still needed in the field of solar cell research in China. The generation of photovoltaic energy in China presents economic and environmental viability with the potential to reduce the initial investment required in photovoltaic modules and photovoltaic power generation systems, to reduce the generation cost and final distribution price (Tan et al., 2012).

The development of the solar system is related to the increase in incentives of the Chinese government system, contributing to the reduction of emission of polluting gases in industrial sectors and the contribution to international environmental commitments in the reduction of risks (Li et al., 2020). The improvement in the energy infrastructure of the industrial sector benefits the use of resources for the generation of renewable energy, job creation and green marketing (Chen et al. 2013).

In addition, with the largest number of publications in the area, Spain has the potential to develop photovoltaic energy due to being one of the countries with the most hours of sunshine on the European continent. Regions in Spain that are considered to be less productive for generating solar energy, still receive more irradiation per year than the average in Germany, the leading country in promoting photovoltaic solar energy. In the photovoltaic market, Spain has an average annual growth estimate of 11.2 GW until 2028 (Corona et al., 2017; Rey-Martínez et al., 2008).

It is noticed that the photovoltaic energy development policies in developed countries like China and Spain, are already at an advantage when compared to developing countries like India and Iran. The accelerated growth of the photovoltaic market shows that solar energy is a viable source for reducing 
emissions related to the world electricity sector. For countries that experience crises through water generation, it may be a solution for prolonged periods of drought (Li et al., 2020; Corona et al., 2017; Chen et al. 2013; Tan et al., 2012; Rey-Martínez et al., 2008; Contreras et al., 1999).

With the objective of guaranteeing a sustainable future and researching the impacts related to climate change, which has become more and more frequent, essentially the issue of global warming, countries with the developing economy urgently seek to change their energy habits fossil fuel for renewable energy. Since solar energy is free and non-polluting, it is considered a choice for less environmental impact and is increasingly expanding the competitive market in renewable energy options (Adenle, 2020; Ha et al., 2020; Venkata Sai \& Reddy, 2020). The classification of the journals of the 22 selected final articles, as by Figure 5 .

Figure 5

Number of publications per journal

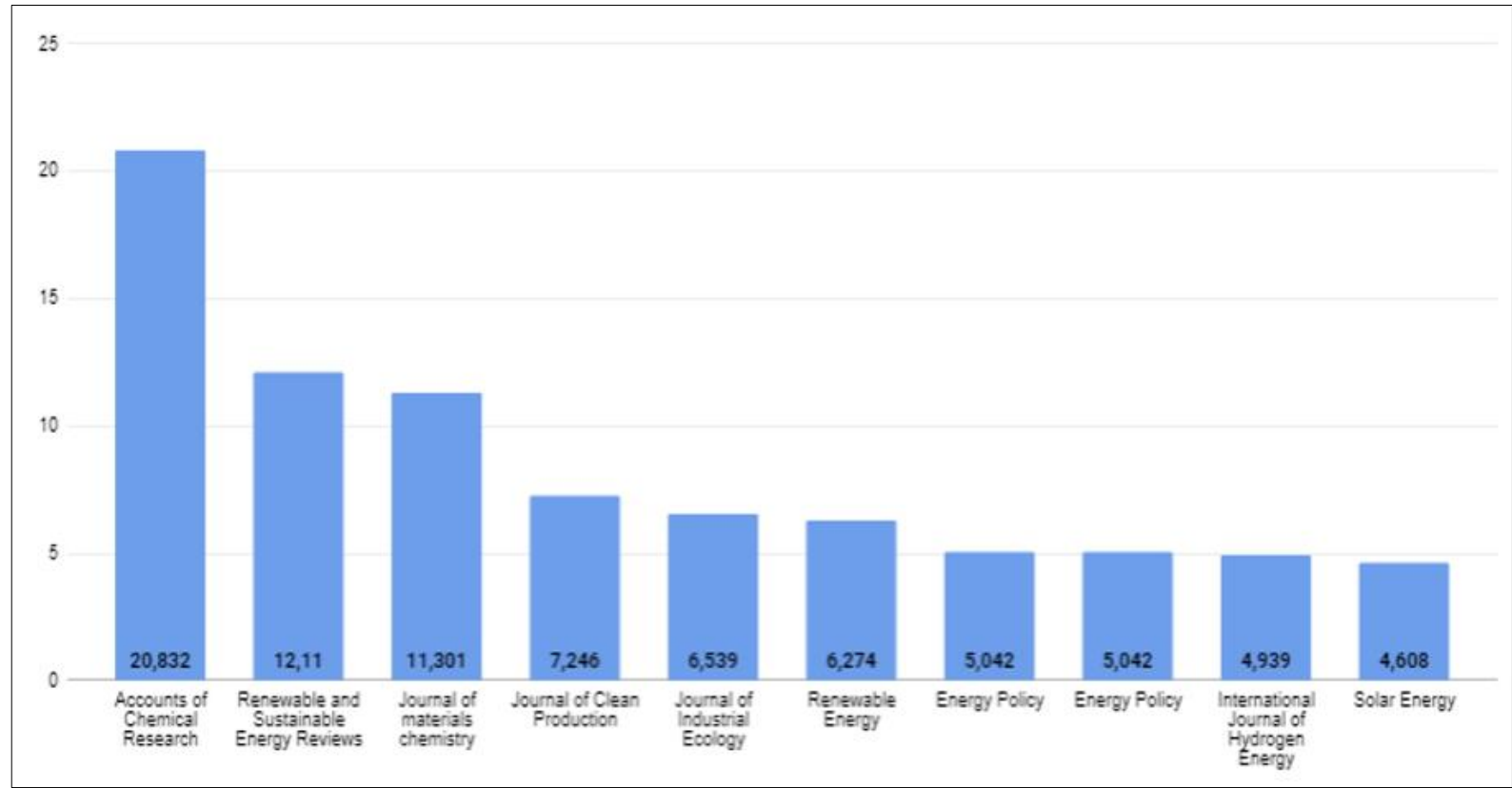

Source: Own Authorship (2020).

The top 10 journals have published 209 articles, representing 100\% of the papers in the sample. Accounts of Chemical Research, Renewable and Sustainable Energy Reviews, Energy Procedia, International Journal of Hydrogen Energy, Energy Policy, Journal of Industrial Ecology, Environmental Engineering Science, Renewable Energy, Environmental Management and Journal of Energy Engineering are the leader on both indicators (JCR 2019). They are journals that perfectly fit the theme of the study. Since 2002, they are the only journals in research on the environmental impacts avoided with the use of photovoltaic energy in the industrial sector (Li et al., 2020; Noh et al., 2020; Stoicanescu et al., 2019; Shlikhter, 2018; Corona et al., 2017; Hamid et al., 2016). Previous reviews have also highlighted its 
importance in the field (Sharon \& Reddy, 2015; Chen et al., 2013; Tan et al., 2012; Rey-Martínez et al, 2008; El-Shobokshy \& Al-Saedi, 1993).

In the literature, it is observed that environmental impacts decrease with the use of clean energy sources, responding to the need for more responsible corporate governance policies and forms in the sector, adding the involvement of stakeholders in the processes (Adenle, 2020; SamaniegoRascón et al., 2019). Photovoltaic solar energy favors the impact avoided by carbon emissions and the reduction in waste generation in the industrial sector (Venkata Sai \& Reddy, 2020; Shlikhter, 2018). Therefore, there are studies that assess the optimization of these effects (Ha et al., 2020; Grippo et al., 2014; Lamont \& El Chaar, 2011). Other papers investigates the damage to climate change (Sharon \& Reddy, 2015; Tan et al., 2012; Branker \& Pearce, 2010; Rey-Martínez et al., 2008). On top of it, Figure 6 presents the co-occurrence of terms in a timeline, and their interrelationships.

\section{Figure 6}

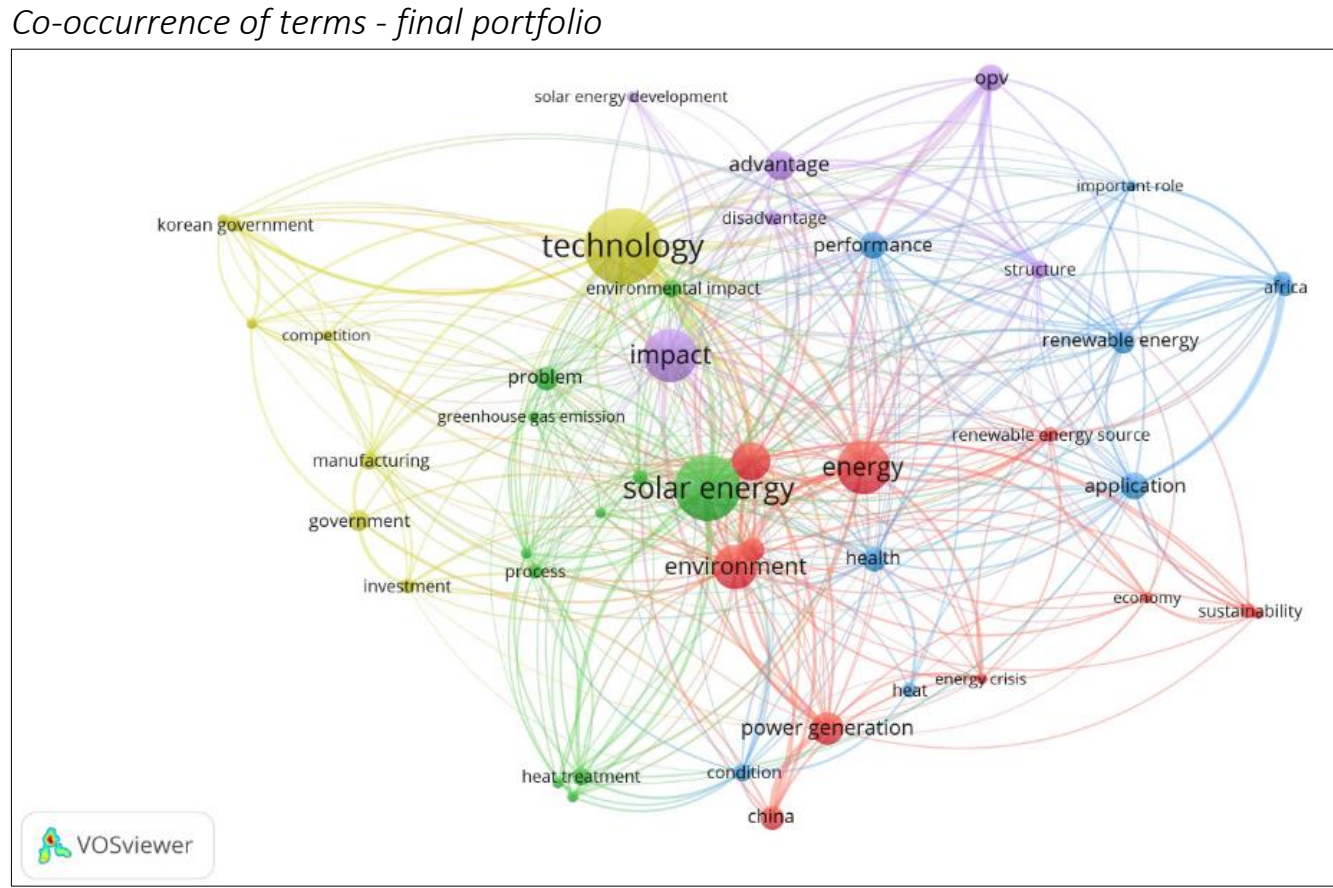

Source: Own Authorship (2020).

Results are based on the final set of 22 articles considered of high impact having gone through the whole set of ruling out criteria, described in the Methods section. The theme is new and seeks development. In light of that, Figure 4 presents the co-occurrence of terms in a timeline, and their interrelationships. Various topics have been addressed within the theme of use of photovoltaic energy in the industrial sector. As Figure 4 shows the terms in the median of the years of their appearance, it is possible to conclude that terms in red (energy, environment, power generation, China, renewable energy source) are subject of the first high impact studies, according to the filters applied in this study. Moreover, the terms in yellow and shades of green comprise more recent approaches, once they appear 
only in the last few years. On top of it, Figure 7 presents the co-occurrence of authors in a timeline, and their interrelationships.

Figure 7

Co-ocurrence of authors

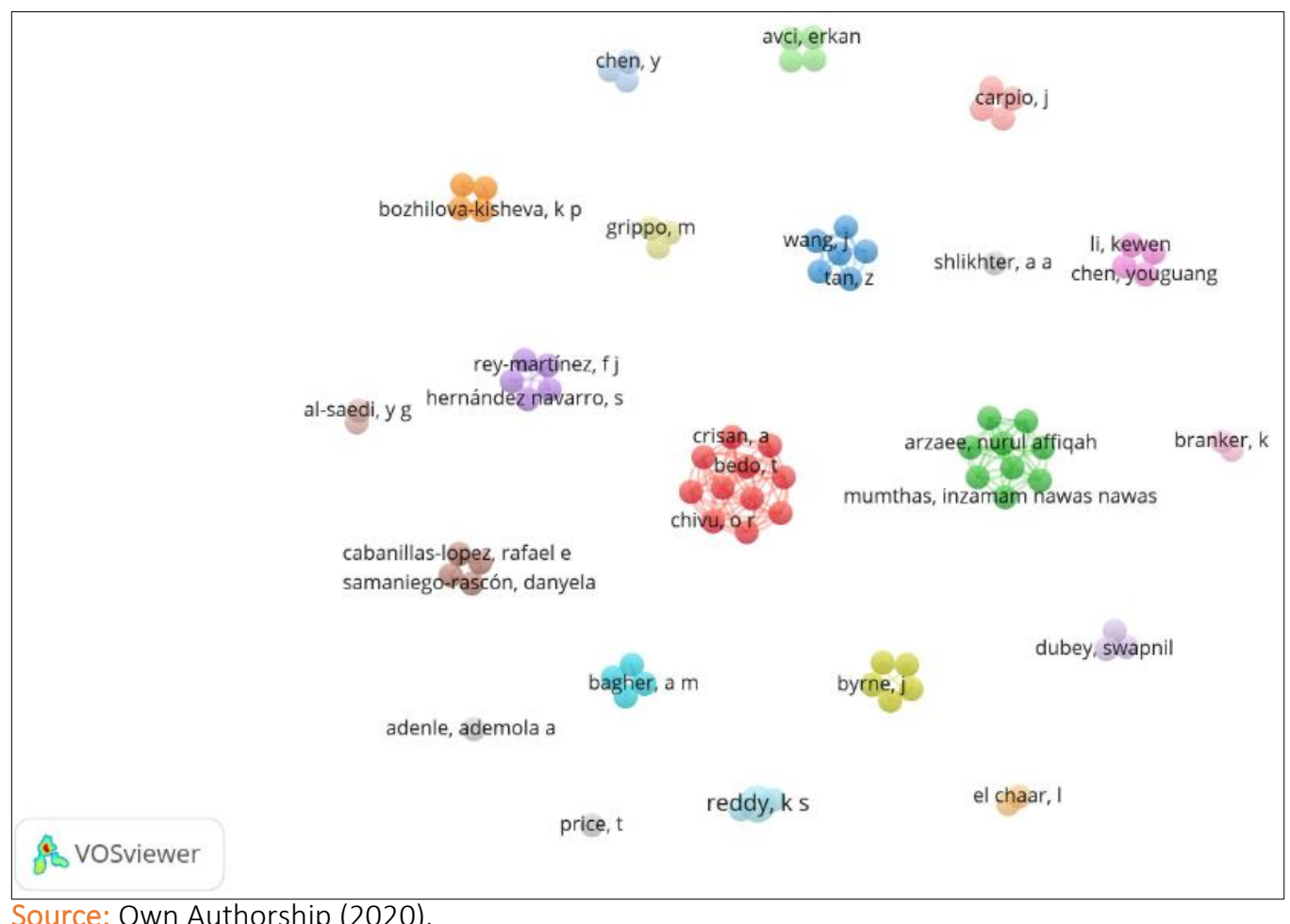

The largest cluster is the red cluster formed by 11 authors, the use of solar energy as clean technologies seeks to minimize the environmental impact in the processing of industrial materials, as well as in industrial processes, with a view to the use of fossil fuels. Electric energy from solar sources does not emit greenhouse gases (GHG) or any other important environmental impact (Stoicanescu et al., 2019; Adenle, 2020); electric energy from solar sources does not emit greenhouse gases (GHG) or any other important environmental impact (Noh et al., 2020); solar energy contributes to diversification of the industrial energy matrix (Chen et al., 2013); solar energy reduces demand for energy in utilities (Sharon \& Reddy, 2015); photovoltaic solar energy is an available and sustainable resource to minimize environmental impacts (Hamid et al., 2016; Rey-Martínez et al, 2008); sustainable energy avoiding energy interruptions in industrial systems (Grippo et al., 2014); possibility of generating sustainable industrial energy for more than 20 years (Ha et al., 2020; Adenle, 2020; Sharon \& Reddy, 2015; Chen et al., 2013; Dubey et al., 2013; Branker \& Pearce, 2010); industrial installation of solar panels allows rapid adaptation of animals of various species (Venkata Sai \& Reddy, 2020); solution for periods of drought (Samaniego-Rascón et al., 2019). 
Therefore, in the Sustainable Development Strategy, there are several measures aimed at obtaining electricity from clean energy sources in the industrial sector so as not to generate negative effects on the environment, which means that industrial expansion of photovoltaic solar energy is desirable (Adenle, 2020; Ha et al., 2020; Noh et al., 2020; Samaniego-Rascón et al., 2019; Corona et al., 2017; Rey-Martínez et al., 2008). The research shows the main developments on the topic of environmental impacts avoided with the use of photovoltaic solar energy in the industrial sector from 1993 to 2020 (As observed in Figure 8).

Figure 8

Photovoltaic solar energy timeline in industry

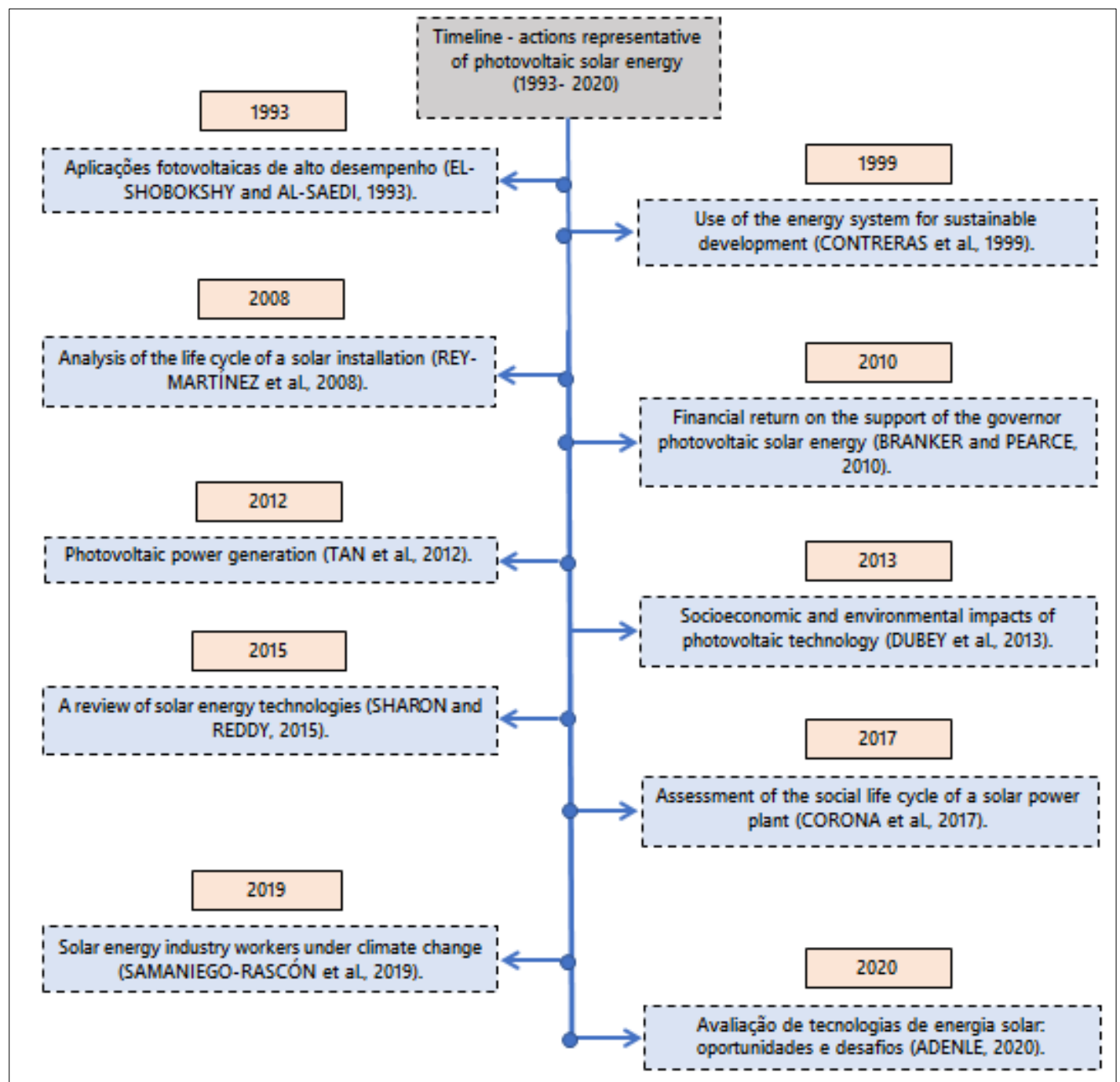

Source: Own Authorship (2020).

According to Figure 8, environmental actions are perceived in the industrial sector in relation to the use of photovoltaic solar energy. However, some aspects are still in the process of transformation, such as: photovoltaic solar energy reduces global warming and its worrying impacts (El-Shobokshy \& Al- 
Saedi, 1993); renewable technology decreases the annual impact of industrial manufacturing systems (Contreras et al., 1999); enables the reuse of industrial materials (Rey-Martínez et al., 2008); reuse of degraded or unused areas (Branker \& Pearce, 2010); increase in the use of solar energy in industries avoiding the emission of CO2 (Tan et al., 2012); lower cost energy in the long run without impacting the ecosystem (Dubey et al., 2013); energy can be used in remote places allowing construction in industrial plants in remote places (Sharon \& Reddy, 2015); decreasing the use of nuclear energy (Corona et al., 2017); minimizing water and air pollution (Samaniego-Rascón et al., 2019); preventing acid rain (Adenle, 2020).

Solar photovoltaic technology is clean, operates without the use of toxic waste such as radioactive materials and a low maintenance system (Venkata Sai \& Reddy, 2020); the expansion potential of the solar photovoltaic market favours and reduces environmental problems (Shlikhter, 2018); renewable solar energy has remarkable potential to meet energy requirements (Hamid et al., 2016); Solar energy is entirely renewable, clean and environment-friendly, with no harmful emissions and can supply electricity needs (Adenle, 2020); use of solar energy is a sustainable form of energy in the rural environment (Ha et al., 2020; Contreras et al., 1999).

\section{Final Considerations}

This article presented a systematic review of the literature on the potential environmental impacts avoided with the use of photovoltaic energy in the industry. The classification and choice of articles to be identified as such to be fully evaluated. From the final portfolio of this study, some conclusions can be drawn. The research in that body of literature is still incipient and it cannot be said that it is following solid trends so far. It is observed that the concern with the environmental impacts with the use of clean sources of energy is still in its initial stage in the industry, yet to be developed and defined.

In addition, most high-impact research was carried out in China, Spain and the United States, with a small participation of countries such as India, Canada, Singapore, Saudi Arabia, United Arab Emirates, Iran, Turkey, Malaysia, Romania, Korea and Russia. With profound insights offered by the scientists in the future, further exciting discoveries are certainly awaiting to be realized.

The use of clean energy sources shows an interesting potential for the environment, with the diversification of the industrial energy matrix being fundamentally sustainable, due to the increased demand for energy by industrial production systems and concerns with the environment. In this sense, the generation of photovoltaic solar energy is essential to reduce damage to the environment, as it is an inexhaustible source. The industrial use of photovoltaic solar energy is considered a possibility for the reduction of $\mathrm{CO} 2$ and global warming on the planet. With the industrial development of photovoltaic energy, the rate of energy generation from fossil sources will be lower, reducing environmental impacts. 
Solar photovoltaic technology shows a positive effect for the environment in reducing the emission of gases responsible for the greenhouse effect and the possibility of commercializing the energy generated. This clean source of energy contributes to the increase in demand for electricity in the world, environmental regulations in the industrial market, concerns with the recovery of the environment, the reuse of degraded environments and contaminated water.

The generation of clean energy alternatives impacts the industrial energy matrix for climate control. Among the advantages in the generation of clean energy alternatives: the diversification of the energy matrix, climate control, reduction in the demand for energy in the concessionaires, reduction of the annual impact of the industrial manufacturing systems, reuse of degraded or unused areas, lower cost of long-term energy without impacting the ecosystem, use in remote locations, reduction of acid rain, sustainable energy avoiding energy interruptions in industrial systems, solution for periods of drought, generation of sustainable industrial energy for more than 20 years and consequently the reduction of environmental impacts. Among the technical advantages, photovoltaic panels show incentives from government systems, little maintenance, competitive advantage for the industrial sector, the process for installing solar panels is accessible and collaboration for a sustainable awareness process for employees and customers.

\section{Acknowledgements}

The authors acknowledge the financial support from the National Council for Scientific and Technological Development - Processes 311807/2018-6 and 428650/2018-0 - CNPq (Brazil)

\section{References}

Adenle, A. A. (2020). Assessment of solar energy technologies in Africa-opportunities and challenges in meeting the 2030 agenda and sustainable development goals. Energy Policy, 137, 111-117. https://doi.org/https://doi.org/10.1016/j.enpol.2019.111180

Branker, K., \& Pearce, J. M. (2010). Financial return for government support of large-scale thin-film solar photovoltaic manufacturing in Canada. Energy Policy, 38(8), 4291-4303. https://doi.org/10.1016/j.enpol.2010.03.058

Castro, V., \& Frazzon, E. (2017). Benchmarking of best practices: an overview of the academic literature. Benchmarking: An International Journal, 24(3), 750-774. http://doi.org/10.1108/BIJ03-2016-0031

Chen, Y., Wan, X., \& Long, G. (2013). High performance photovoltaic applications using solution- 
processed small molecules. Accounts of Chemical Research, 46(11), 2645-2655.

https://doi.org/10.1021/ar400088c

Contreras, A., Carpio, J., Molero, M., \& Veziroglu, T. N. (1999). Solar-hydrogen: An energy system for sustainable development in Spain. International Journal of Hydrogen Energy. 24(11), 1041 1052.

Corona, B., Bozhilova-Kisheva, K. P., Olsen, S. I., \& San Miguel, G. (2017). Social Life Cycle Assessment of a Concentrated Solar Power Plant in Spain: A Methodological Proposal. Journal of Industrial Ecology, 21(6), 1566-1577. https://doi.org/10.1111/jiec.12541

Duarte, C. G., \& Malheiros, T. F. (2015). Sustentabilidade e Políticas Públicas para o setor sucroenergético: uma análise dos temas abordados. Revista Gestão Ambiental e Sustentabilidade, 4(3), 122 - 138.

Dubey, S., Jadhav, N. Y., \& Zakirova, B. (2013). Socio-Economic and Environmental Impacts of Silicon Based Photovoltaic (PV) Technologies. Energy Procedia, 33, 322-334. https://doi.org/https://doi.org/10.1016/j.egypro.2013.05.073

Elgamal, G. N. G., \& Demajorovic, J. (2020). Barriers and perspectives for electric power generation out of photovoltaic solar panels in the brazilian energy matrix. Journal of Environmental Management \& Sustainability, 9(1), 1-26, e17157. https://doi.org/10.5585/geas.v19i1.17157.

Elsevier. 2020. "Research Platforms". 2020. Accessed 20 July 2020. https://www.elsevier.com/ptbr/research-platforms.

El-Shobokshy, M. S., \& Al-Saedi, Y. G. (1993). The impact of the gulf war on the Arabian environment-I. Particulate pollution and reduction of solar irradiance. Atmospheric Environment Part A, General Topics, 27(1), 95-108. https://doi.org/10.1016/0960-1686(93)90074-9

Grippo, M., Hayse, J. W., \& O’Connor, B. L. (2014). Solar Energy Development and Aquatic Ecosystems in the Southwestern United States: Potential Impacts, Mitigation, and Research Needs. Environmental Management, 55(1), 244-256. https://doi.org/10.1007/s00267-014-0384-x Ha, Y. H., Byrne, J., Lee, H.-S., Lee, Y.-J., \& Kim, D.-H. (2020). Assessing the impact of R\&D policy on PV 
market development: The case of South Korea. Wiley Interdisciplinary Reviews: Energy and Environment, 9(2). https://doi.org/10.1002/wene.366

Hamid, B., Bagher, A. M., Reza, B. M., \& Mahboubeh, B. (2016). Review of sustainable energy sources in Kerman. World Journal of Engineering, 13(2), 109-119. https://doi.org/10.1108/WJE-042016-014

Korkmav, H., Unsal, O., Gorgun, H. V., \& Avci, E. (2020). Energy Efficiency in Lumber Drying - Sample of Drying Red Pine (Pinus brutia) Using Solar Energy. Journal of polytechnic-politeknik dergisi, 23(3), 671-676.

Lamont, L. A., \& El Chaar, L. (2011). Enhancement of a stand-alone photovoltaic system's performance: Reduction of soft and hard shading. Renewable Energy, 36(4), 1306-1310. https://doi.org/10.1016/j.renene.2010.09.018

Li, K., Liu, C., Jiang, S., \& Chen, Y. (2020). Review on hybrid geothermal and solar power systems. Journal of cleaner production, 250. https://doi.org/10.1016/j.jclepro.2019.119481

Noh, M. F. M., Arzaee, N. A., Mumthas, I. N. N., Mohamed, N. A., Nasir, S. N. F. M., Safaei, J., \& Teridi, M. A. M. (2020). High-humidity processed perovskite solar cells. Journal of materials chemistry A, 8(21), 10481-10518. https://doi.org/10.1039/d0ta01178a

Norris, M., \& C. Oppenheim. 2007. Comparing alternatives to the Web of Science for coverage of the social sciences' literature. Journal of Informetrics, 1(2): 161-169. doi: 10.1016/j.joi.2006.12.001.

Paines, P. A., Vignochi, L., Possamai, O. (2018). Simulation of photovoltaic systems for commercial sector. Exacta - EP, 16(3), p.17-30.

Price, T. (2008). Making the case for solar energy. Optics and Photonics News, 19(10), 18-19. Retrieved from https://www.scopus.com/inward/record.uri?eid=2-s2.057849131331\&partner|D=40\&md5=7e27a3d2caee1e823b83c9398b61bca0

Rey-Martínez, F J; Velasco-Gómez, E; Martín-Gil, J; Navas Gracia, L M; \& Hernández Navarro, S. (2008). Life cycle analysis of a thermal solar installation at a rural house in Valladolid - Spain. 
Environmental Engineering Science. 25(5), 713-724.

Samaniego-Rascón, D., Gameiro da Silva, M. C., Ferreira, A. D., \& Cabanillas-Lopez, R. E. (2019). Solar energy industry workers under climate change: A risk assessment of the level of heat stress experienced by a worker based on measured data. Safety Science, 118, 33-47. https://doi.org/https://doi.org/10.1016/j.ssci.2019.04.042

Sharon, H., \& Reddy, K. S. (2015). A review of solar energy driven desalination technologies. Renewable and Sustainable Energy Reviews, 41, 1080-1118. https://doi.org/https://doi.org/10.1016/j.rser.2014.09.002

Shlikhter, A. A. (2018). Paris climate conference and priorities of donald trump's energy policy. World Economy and International Relations, 62(12), 65-74. https://doi.org/10.20542/0131-22272018-62-12-65-74

Stoicanescu, M., Crisan, A., Milosan, I., Pop, M. A., Garcia, J. R., Giacomelli, I., \& Chivu, O. R. (2019). Heat treatment of steel 1.1730 with concentrated solar energy. Materiale Plastice, 56(1), 261270. https://doi.org/10.37358/mp.19.1.5163

Tan, Z., Zhang, H., Xu, J., Wang, J., Yu, C., \& Zhang, J. (2012). Photovoltaic power generation in China: Development potential, benefits of energy conservation and emission reduction. Journal of Energy Engineering, 138(2), 73-86. https://doi.org/10.1061/(ASCE)EY.1943-7897.0000062

Van Raan, A.F. (2003). The use of bibliometric analysis in research performance assessment and monitoring of interdisciplinary scientific developments. Technology Assessment-Theory and Practice, 1(12), 20-29. https://doi.org/10.14512/tatup.12.1.20

Venkata Sai, P., \& Reddy, K. S. (2020). 4-E (Energy-Exergy-Environment-Economic) analyses of integrated solar powered jaggery production plant with different pan configurations. Solar Energy, 197, 126-143. https://doi.org/https://doi.org/10.1016/j.solener.2019.12.026 